\title{
奈良町における街並み景観保全のための町屋の意匠構成要素に基づく 造形ライブラリーに関する研究 \\ PARAMETRIC DESIGN LIBRARY OF TRADITIONAL JAPANESE TOWN HOUSES FOR PRESERVATION OF THE STREET LANDSCAPE AT NARA-MACHI
}

\author{
渡辺 俊*, 暮城 桂子** \\ Shun WATANABE and Keiko KATSURAGI
}

\begin{abstract}
Today, preservation of the traditional street landscape is one of the biggest concern to the urban planning and design. In this paper, the analysis of design elements is described which constitute the elevations of traditional Japanese town houses at NARA-MACHI. Then, the development of knowledge-based parametric design library is explained to assist urban design simulation for reproduction of the street landscape. The 12 components, e.g. a tiled roof and a lattice window, are prepared which can metamorphose their shapes according to the traditional architectural design rules. Using the library, the complex elevation of an existing traditional town house can consist of some objects, and also can be transformed for alternatives with the minimum change of parameters.
\end{abstract}

Keywords: elevation, lattice window, $C A D$, parametric design, shape grammar ファサード、格子葖、CAD、パラメトリックデザイン、形態文法

\section{1.はじめに}

近年、伝統的街並みの評価が高まっており、自治体等による景観 施策の中で、伝統的建造物群保存地区に定めて建物の外観を保全し たり、伝統的街並みを重視した景観条例に基づく環境整備を進める ようになりつつある。このような政策を支える背景の一つには、新 規開発が中心であった都市計画から、住民参加によるまちづくりへ という時代の要請が挙げられ、景観保全を目的とした調査・ワーク ショップ・修景の現場において、景観シミュレーション等を用いた 街並みイメージの共有化のために、簡便に伝統的街並み景観を再現 できる手法が求められている。

一方、町屋・伝統的街並みについては、建築・都市計画分野の中 で、これまでも様々な立場から学術調査・研究が行われてきた。

町屋・伝統的街並みについて、早くからその価値に着目したもの に、例えば上田らの研究がある"2!。そこでは、歴史的な視点からそ の成立過程を分析し、日本各地の町屋について実測を行ない、また 社会的コミュニティにまで言及するなど、広く町家論を展開した。

また川崎らは、京都の伝統的街並みについて構成要素を写真や図 を用いて分類整理し、計画論的視点から空間構成の巧みさを解明し ている3。門内は、全国の伝統的街並みをくまなく調査するとともに、 記号論の立場からこれをより精繳に記述することに成功している゙。 これらの研究は、伝統的街並みの豊かさが造形的言語による記号的
空間にあることを明らかにしたものとして高く評価されるものであ る。しかし、その内容はデザインの分析が中心あるいは定性的な記 述・意味の抽出に焦点が当てられており、具体的町屋の仔細な意匠 が生成可能なデザイン手法の提示はなされていない。

一方、生成可能なデザイン手法の研究としては、情報システム分 野において、Mitchellらが、オーダーを生成的知識としてギリシャ・ ローマ建築の柱様式を再現するパラメトリックデザインの手法を提 示している゙ 。渡辺は、建築一般についてその構成要素を知識工学の 立場から分類整理し、情報技術で言うところのオブジェクトとして デザインプロセスに従った意匠構成ルールを内包することで、より 簡便な設計支援システムが記述できることを明らかにしだ》。その 後同様の視点から、CADシステムの開発現場においてもオブジェク トによる機能拡張が進められるようになったが、いずれも現代建築 の設計実務が念頭に置かれており、日本の町屋・伝統的街並みにつ いて真摰に適応を試みた研究は行われていない。

\section{2. 研究目的}

そこで本研究では、伝統的街並み景観にとって最も影響のある町 屋のファサードを対象とし、奈良町を事例として、街並み景観の簡 便な記述・操作を可能とする、町屋の意匠構成要素に基づいた造形 ライブラリーを開発することを目的とする。
$*$ 筑波大学社会工学系 助教授・博士 (工学)

** 筑波大学社会工学研究科 大学院生
Assoc. Prof., Institute of Policy and Planning Sciences, University of Tsukuba, $\mathrm{Ph}$. D.

Graduate Student, Doctoral Program of Policy and Planning Sciences, University of Tsukuba 


\section{3. 奈良町の概要}

奈良町は、伝統的建造物群保存地区に定めら扎てはいなりのの、 独自の景観条例に基づいて街业み景観の保全を行っている地区とし て有名である。

元興寺を中心に南北に走る上ツ道と東西に走る清水通りから周辺 へ都市景観形成地区として指定さ机た約48.1 haの地域には、奈良ま ちづくりセンターの努力により、近世・近代の町屋が数多く保存 . 再生され、今日では多くの観光客で眼わっている。奈良町という行 政区域はなく、元興寺町、芝新屋町、坂新屋町、木辻町、陰陽町な ぞ小さな町割りが集った地域に、そ扎ぞれの歴史的背景に応じた様々 な表棈えの町屋が伝統的街业み景観を今に伝えている。

一方で、伝統的建造物群保存地区のような強い增改篹の制限が行 われている訳ではなく、空き地が駐車場として暫定利用されていた り、現代風にアレンジした新町屋に建て変わるなど、簡便な景観シ ミュレーション手法が望まれる地区でもある。

\section{4. 町屋ファサードの分析}

2000 年 01 年に筆者らが独自に行った現地調查、1981年〜87年 に実施された伝統的建造物群保存対策調査報告書" 原形を明らかにするために、明治時代に描か扎た銅版西'"”を用いて、 奈良町における町屋の意匠構成要素の抽出を行った。対象とした町 屋は、筆者らの現地調査で199件（非伝統的様式を含む）、伝統的建 造物群保存対象調查報告書から120件、銅版面から114件である。

伝統的町屋ファサードを構成する意匠構成要素については、既に 慣習化された建築言語が確立している。そ扎らは「尉子二階」とい った空間的領域を表すものから「鳥筌」といった詳細部位に至るま で様々である。門内は、街业み記号論という立場から、タウンテク スチャーを構成する記号のレパートリーについて、知覚的層、形態 的層、位相的層があることを主張している。そして、形態的層にお ける記号のレパートリーについて、平面図形の直和分割という純粋 に幾何学的分割と建築言語によって抽出された記号を「カテゴリー」 として扱い、それぞれのカテゴリーの特徵をバリエーション[標識] とみなした結果、建築については、主屋部分を23のカテゴリーに、 付属物部分を3つのカテゴリーに分類できるとした"”。

本研究では、これをカテゴリーの基準として、町屋のファサード を構成する基本的な意匠構成要素について、まずその出現度合いを 整理しリストを作成した。特に、明治の銅版画にまで遡ることで、 意匠構成要素の中には現在はほとんど見られなくなっているが、揚 見世や連続した大戸による広い開口など、明治期には多数設えられ ていた要素があることも明らかになった。逆に、京都の町屋では広 く用いられる犬矢来は、それほど多くは観察されなかった。

続いて、位相的層を明らかにするために、作成された意匠構成要 素のリストを基に、渡辺の研究》れを参考に、奈良町のそれぞれの町 屋について、抽出された意匠構成要素によるファサードの構造を夕゙ イアグラムとして再構築することを試みた。一例として、写真1の 左側は奈良町の特徴をよく表した東城户町の町屋の外観であり、図 lがその基本的意匠構成要素のダイアグラムである。また別の事例 として、写真1の右側は芝新屋町に現存する籠空の配置が特徴的 な町屋の外観であり、図2がそのファサードの構成要素のダイアグ ラムである゙た。

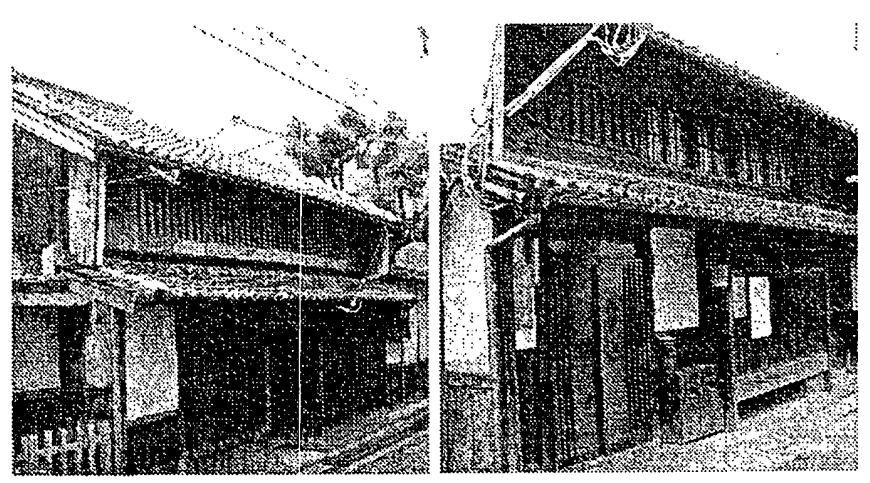

写真1 奈良町の町屋の外観

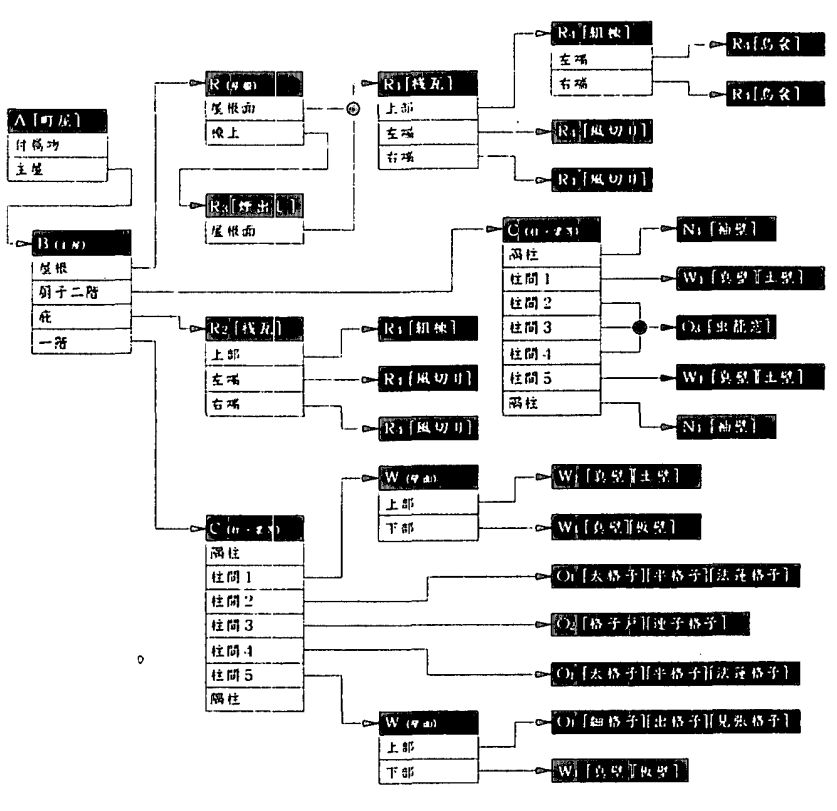

図1 町屋1ファサードのダイアグラム

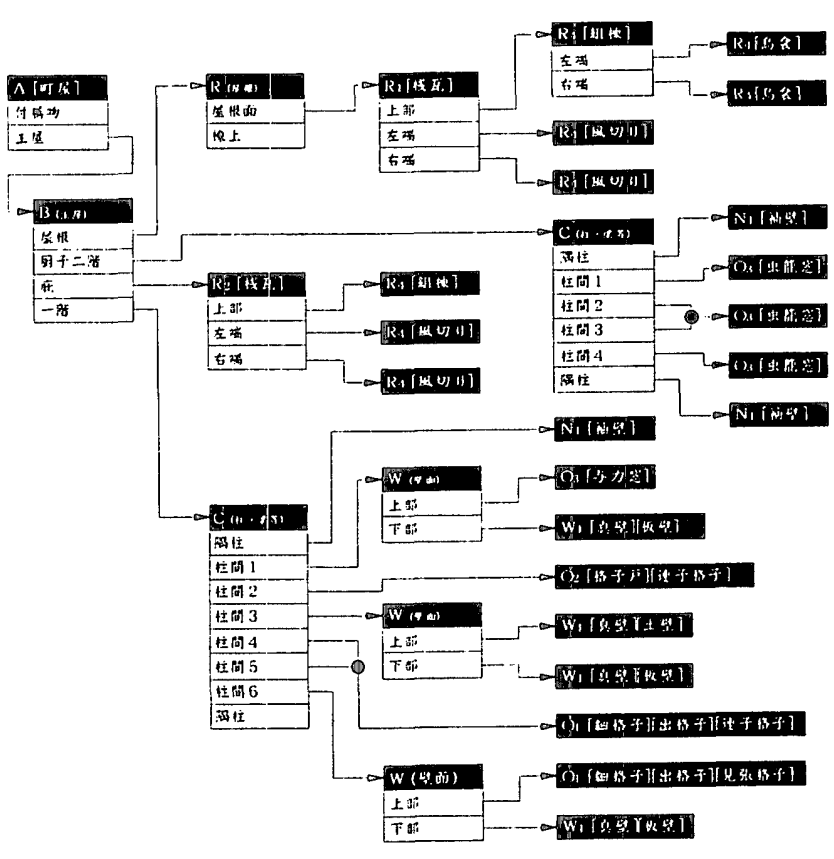

図2 町屋2ファサードのダイアグラム゙:》 
図1、2において、黒枠はカテゴリーを、[]内の值はバリエーショ ンの標識を、白枠はカテゴリー間の位相的関係を明示するために付 加したスロットである。同様にして主要な調査対象全てのダイアグ ラムを描いた結果、奈良町の町屋のファサードはいず扎も類似した 構造で記述可能であり、「町屋」を起点としてトップダウンに意匠構 成要素を選択的に指示することにより再現できることが確認された。 特に、ダイアグラムにおける主な相違はその構造ではなくカテゴリ 一における標識の違いであり、造形ライブラリー構築のために以下 のような構成単位分割の指針が読み取れた。

(1) 奈良町における町屋の主屋のファサードを構成する四つの領域 （屋根部分、㴻子二階部分、庇部分、一階部分）は、互いに独 立したクラスターに分割される。ただし、欴子二階部分、庇部 分が無い町屋もある。

（2）一階部分と欴子二階部分の柱間は必ずしも一致しないが、間口 幅は建物全体で等しい（パラメータを共有する)。

（3）煙出しがある場合、その意匠構成要素パターンは母屋のそれを 踏襲する (パラメー夕を共有する)。

（4）格子空と虫籠窓は、複数の柱間を跨いで設えられる場合がある。

（5）壁面の意匠は上下二段構成となったり、与力空や戸袋等が付带 する場合があるが、柱間内で完結する。

なお、ダイアグラム自体は構成要素間の定性的な関係の記述であ り、それだけで具体的町屋の仔細な意匠を再現することは不可能で ある。造形ライブラリーとするためには、定量的な視点から、それ ぞれの意匠構成要素について、その寸法的納まりの制約ルールが必 要となる。そこで、それぞれの要素のより細部の寸法について、筆 者らによる現地での実測調査、伝統的建造物群保存対策調查時の実 測図面および関連図書 ${ }^{(5)} よ り$ 整理し、その形態を再現するためのパ ラメータの検討を行った。

\section{5. 造形ライブラリーの構築}

造形ライブラリーの構築にあたり、ライブラリーが広く利用可能 となることを念頭に、VectorWorksの拡張言語であるVectorScript (Pascal) を開発環境として採用し、個々の意匠構成要素をプラグ インオブジェクトとして実現した ${ }^{(4)}$ 。VectorScriptにおけるプラグ インオブジェクトとは、それ自体が図形を生成する手続き（プログ ラム）として実体化されるシンボルであり、入力されるパラメータ により変体するために、町屋の意匠構成ルールをオブジェクトに内 包させることが可能である。

町屋のファサードが簡便に再現可能な造形ライブラリーを考える 場合、プラグインオブジェクトの種類は、現存する奈良町の町屋 アサードのバリエーションを再現できるだけでなく、簡便な景観シ ミュレーションの視点から、同一カテゴリーにおける標識の変更ま でもがオブジェクトの再入力に極力ならないような数に押さえた設 計が必要である。

一方、ファサード全体を単一のオブジェクトとして全ての意匠構 成ルールを一つのて長な手続きとして記述することも技術的には可 能であろう。しかし、全ての場合の数を実現するために準備しなけ ればならないパラメータの数があまりに多くなり一方で、その多く
は組み合わせ的に無駄なものとなる。加えて、パラメータの変更の 度にファサード全ての図形生成が再実行されるために、システムの パフォーマンスの視点から現実的ではない。

また、VectorScriptでは変数の参照は全て当該オブジェクト内か らに限定されており、大域変数を用いることが出来ないため、言語 的制約の視点から、パラメータを共有するサブカテゴリー同志は図 形として合成可能であるならば、より上位のカテゴリーによる一体 のオブジェクトとして記述するべきである。

オペレーションの視点からは、それぞれのオブジェクトの入力に 際して、余分な補助線等を用いずに、先行して入力されているオブ． ジェクトが提供する端点群のみの中から簡便に入力のための制御点 を拾える必要がある。

以上の考察と前章における指針を基に、先に示された $26(23+3)$ のカテゴリーから、調查に扔いて出現頻度が少なかったり判別され なかった要素、ファサードからは見えにくい要素、プラグインオブ ジェクトとしてパラメータを用いた生成手続きとして記述するより 一般的なシンボル図形とした方が適当な点的要素等を除き、残りの 21のカテゴリーについて、その階層構造を考慮して集約・分解し、 以下の 12 種類の構成単位に分割しプラグインオブジェクトとして記 述した注)。

5-1. 構造オブジェクト (C)

最初に入力するオブジェクトであり、小屋高(P1)、階高( $\mathrm{P} 2,6)$ 、 柱幅(P4,8)、柱間(P5,9)、軒・庇・螻羽の出(P10,11,12,14,15,16)等 を定量的パラメータとして、柱、桁、小屋束、棟木、垂木等を一体 の図形として生成する。入力する制御点は、図面上での位置を決め るためのGLの中心一点のみである。棟高については、主屋の平面構 成によっては落ち棟となっている場合もあるので、柱間単位で小屋 高をパラメータとして与えられるようにした。また、一階の柱の位 置と二階の柱の位置が必ずしも一致しないため、通り心ではなく、 それぞれの階の柱間を独立したパラメータとし、全体の間口は相互 に補完させている(図3)。なお、詳細な小屋組の生成は、調査の資 料だけからはその構造が特定できないばかりでなく、他のオブジェ クト入力の参照点として利用されないこと、屋根を真いてしまえば 隠れてしまうことから、省略することとした。

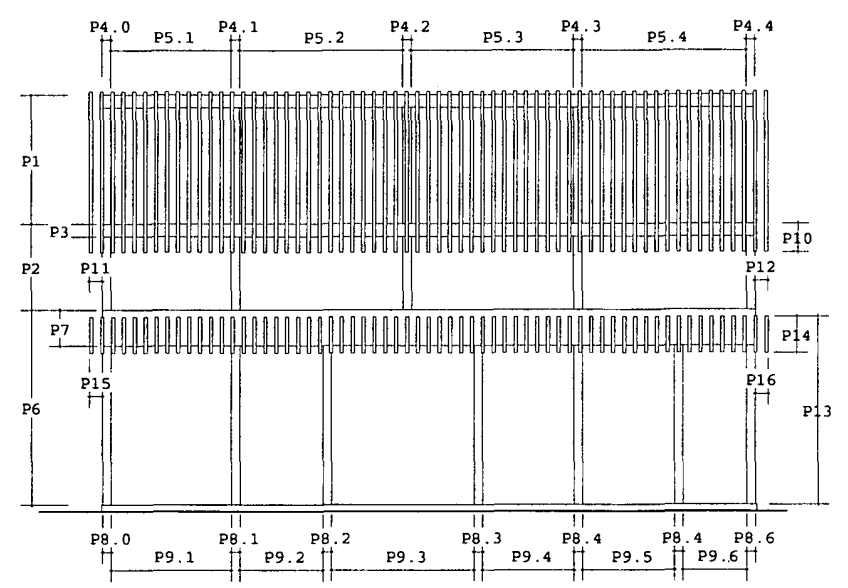

図3 軸組のパラメータ 


\section{5-2. 瓦屋根オブジェクト（R)}

瓦屋根オブジェクトは、軸組オブジェクトにより示される螻羽の 隅三点を指示することで入力することとし、栈瓦／本瓦の別に従っ て屋根面に瓦を割り付けた図形を生成するオブジェクトとして記述 した。また、棟、鬼瓦・巴瓦・鳥食、風切り、煙出し、雨䇶の有無 について、それらの意匠を特定するためのいくつかの定量的補助パ ラメータ $(\mathrm{P} 4 \sim 12)$ と共に実際に奈良町において観察される瓦屋根の ヴァリエーションを生成できるようにした（図4)。なお、瓦以外の 屋根仕上げはほとんど存在しないため、本ライブラリーでは省略す ることとした。

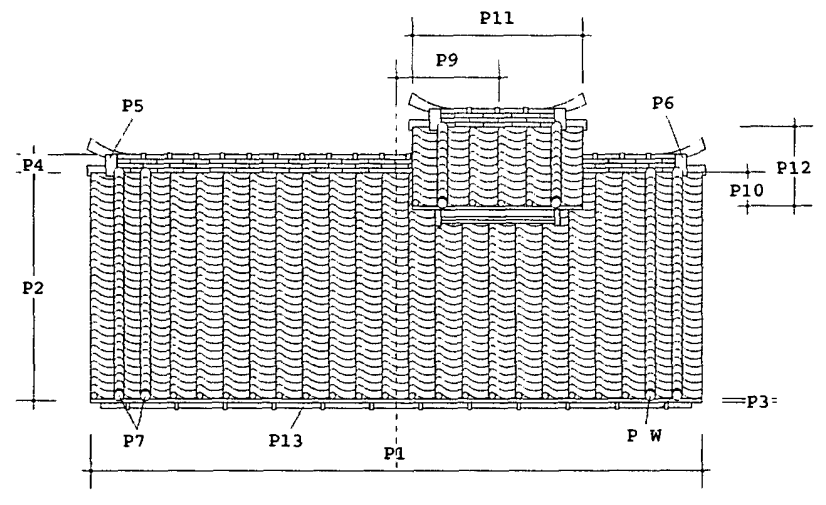

図4 瓦屋根のパラメータ

5-3. 格子悹オブジェクト $\left(\mathrm{O}_{1}\right)$

町屋のファサードを構成する要素として最も重要なのが格子であ り、特に奈良町で見られる法蓮格子は横栈の配置に特徵がある ${ }^{\text {湆。 }}$ この他にも、奈良町において観察される酒屋格子・糸屋格子・仕舞 屋格子・連子格子などの格子のパターンは一見様々な意匠を示すが、 基本的に格子自体は13の定量的パラメー夕（格子の幅・高さ $(\mathrm{P} 1,2)$ 、 横框 - 縦框の幅 $(\mathrm{P} 3,4)$ 、横栈の幅・上段の本数・下段の本数・下段 の空き(P5,6,7,8)、格子竪親の幅・空き $(\mathrm{P} 9,10)$ 、切子竪子の幅・本 数・切詰長さ $(\mathrm{P} 11,12,13))$ により、また平格子／出格子／釣格子の 違いや上部が中敷居で仕切られ連子格子／吹寄せ格子等が納まって いる場合等を描き分けるためのパラメー夕を含めると27の定量的パ ラメータにより、全ての意匠が比較的簡単な同一のアルゴリズムに より生成できることが分かった（図5） ${ }^{\text {i土7。 }}$

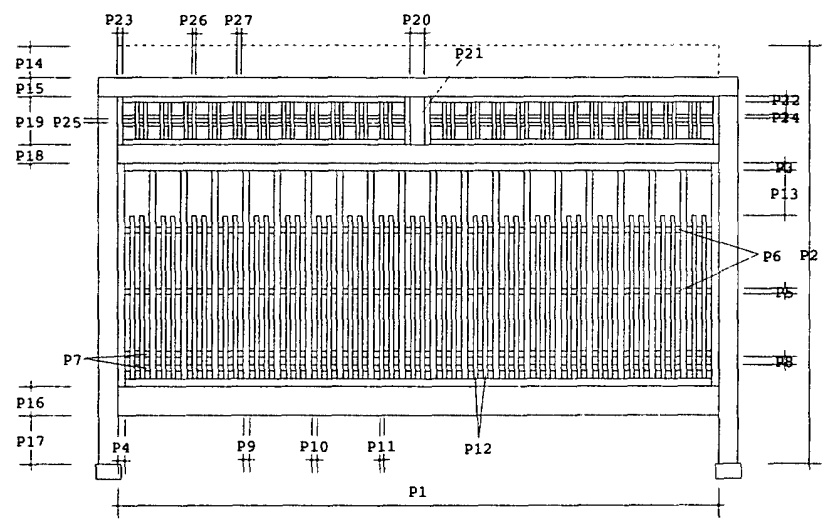

図5 格子窓のパラメータ
5-4. 籠空オブジェクト $\left(\mathrm{O}_{31}\right)$

町屋に特徵的な意匠構成要素であり、特に奈良町では本二階化す ることなく近代まで尉子二階が比較的守られてきたため、造形ライ ブラリーとしては重要な要素である。格子同様、四隅の形状や空枠 の仕立ての違いから一見様々な意匠を示すが、ほほ全ての形態が、 ポリゴンを扱うことが可能なCADシステムの特徵を生かすと、二つ の隅丸長方形の論理和を用いることで、7つの定量的パラメータ（空 の幅・高さ $(\mathrm{P} 1,2)$ 、空枠の幅 $(\mathrm{P} 3)$ 、綐側隅丸長方形・横側隅丸長方 形の曲半径(P4,5)、竪子の幅(P6)・空き(P7)) により簡便にアルゴリ ズム化可能であることが分かった（図6）。

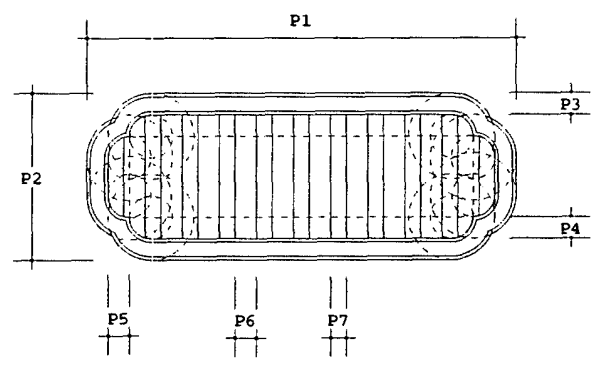

図6 虫籠公のパラメータ

\section{5-5. 戸オブジェクト $\left(\mathrm{O}_{2}\right)$}

軸組オブジェクトにおける柱と桁により囲われる領域の隅三点を 指示することで入力することとし、戸、小壁、小脇壁を一体として 扱うこととした。一般には、戸や葖などの建具は独立したオブジェ クトとして壁オブジェクトに後付けする建築モデルが試みられてお り、これは大壁に建具が複数配置される等を念頭に置いた場合には 有効である。しかし、町屋においては小壁、小脇壁は真壁であり、 方立て、鴨居を介しでと共に柱間に納まっているため、一体とし た方が簡便であろう。手続き的には、19のパラメー夕(まぐさの幅(P3)、 方立の幅(P4)、戸の横位置・幅・高さ(P5,6,7)、上框・下框・縦框の 幅( $\mathrm{P} 9,10,11)$ 等) により、一枚戸の場合には、大戸として隅に潜り 戸が設けられるなどの意匠ルールを記述した（図7）。

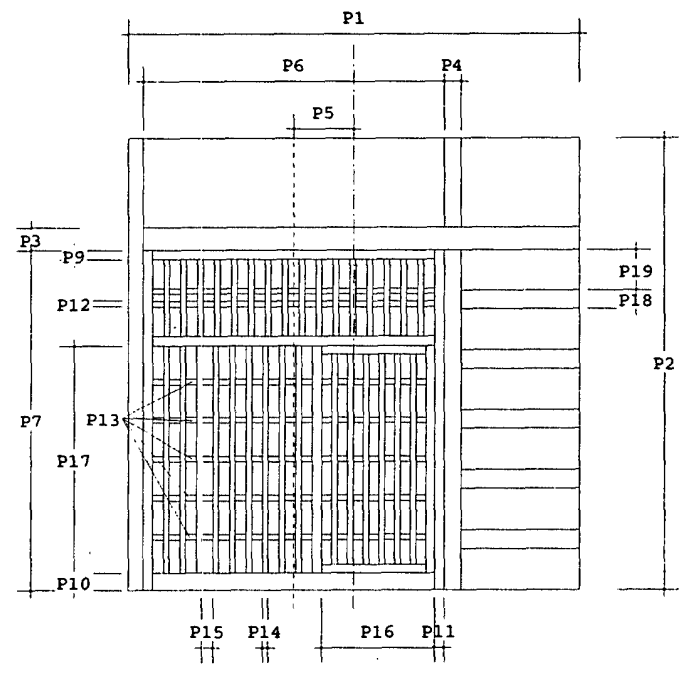

図7 戸のパラメータ 
5-6. 壁オブジェクト（W）

戸オブジェクトと同様に、柱と桁により曲われる領域の隅三点を 指示することで入力することとし、8つの定量的パラメー夕（柱間 の幅・高さ $(\mathrm{Pl}, 2) 、$ 腰高 $(\mathrm{P} 4) 、$ 笠木の高さ $(\mathrm{P} 3)$ 、土台の高さ $(\mathrm{P} 5)$ 、板 幅 $(\mathrm{P} 6)$ 、押縁幅・間隔 $(\mathrm{P} 7,8))$ により羽目板／下見板／海鼠等によ る仕上げの違いに従った壁面の意匠を生成するオブジェクトとして 記述した（図8)。壁面に付帯する戸袋や、腰壁より上の土壁部分に 通常備えられる出格子空や与力公などの意匠構成要素については、 独立したオブジェクトとして記述する方が意匠分類的には適切であ る。しかし、奈良町には一つの柱間にこれらの要素が複数設けられ る事例はなく、戸における小脇壁同様に、壁オブジェクトと一体と して扱った方が、操作が簡便である。そこで、付帯物の有無に関す る定性的パラメータを準備し、図8に示すように、壁オブジェクト の中からでもその意匠を一体として生成できるようにした ${ }^{481}$ 。

\section{5-7. 出格子公／与力空オブジェクト $\left(\mathrm{O}_{32}\right)$}

出格子悹や与力公などの開口部は、15の定量的パラメータ（横・ 縦位置(P9.10)、窓幅・高さ(P11,12)、上框·下框·方立の幅 $(\mathrm{P} 13,14,15)$ 、 上框・方立の角柄の長さ、横栈の幅 - 本数 $(\mathrm{P} 16,17)$ 、堅子の幅・空 き $(\mathrm{P} 18,19)$ 、庇の幅・高さ $(\mathrm{P} 20,21)$ 等 $)$ を用いて、土壁内での位置 の補正をするとともに出格子䓗／与力悹の意匠を生成する手続きを 記述した（図8）理9，現地調査から、出格子空については、一般的な 見張り格子や吹寄せ格子を設えたものだけでなく、菱格子を用いて さらに縦框と方立柱の間に彫刻を納めたものなど独特の工夫がなさ れている場合があり、それら全ての意匠を手続き的に生成すること は不可能なため、代表的事例の生成手続きを記述するに留めた。

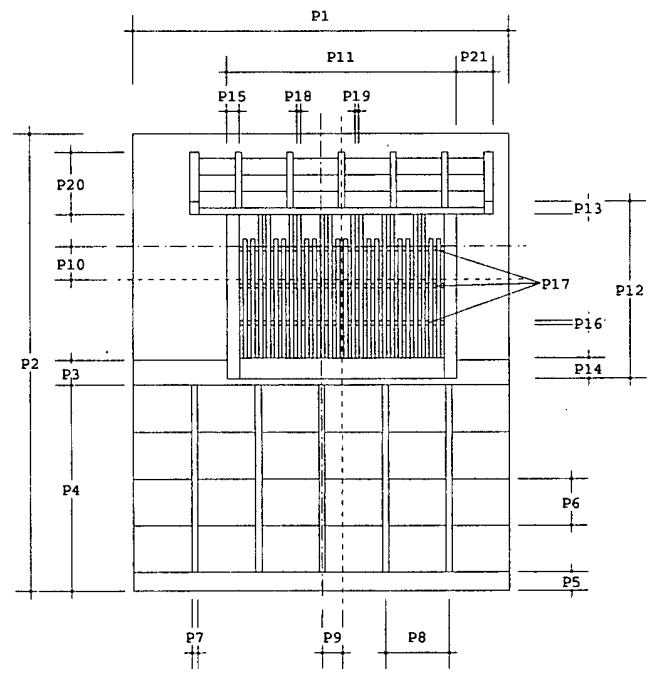

図8 壁・出格子窓のパラメータ

\section{5-8. 袖壁オブジェクト $\left(\mathrm{N}_{1}\right)$}

奈良町の町屋に比較的多く見られる意匠要素であり、隅柱の柱形 に沿って三点を指示することで入力することとしたが、それ自身だ けではエレベーション的にはほとんど判別できない。ただし、卯建 が上がる場合には補助パラメー夕に従って卯建の特徵である小屋根 の意匠を生成するオブジェクトとして記述した。
5-9. 揚見世オブジェクト $\left(\mathrm{N}_{5}\right)$

町屋の意匠構成要素の抽出作業の過程で、奈良町において、昭和 以降にはあまり見られなくなっているものの、過去においてはかな りの町屋で備えられていたことが確認されたので、伝統的町屋の意 匠要素として開閉二つの状態を生成可能なオブジェクトとして用意 した。

5-10. 駒寄せオブジェクト $\left(\mathrm{N}_{4}\right)$

設置する位置のGL上両端二点を指示することで入力することとし、 それぞれ定量的パラメータに従って上側の意匠を生成するオブジェ クトとして記述した。

\section{5-11. 門オブジェクト $\left(\mathrm{H}_{21}\right)$}

軸組オブジェクト同様、設置するGLの中心位置の一点を指示する ことで入力することとし、冠木門／木戸門／薬医門の意匠を、8つ の定量的パラメー夕 (門の高さ $(\mathrm{P} 1)$ 、内法幅・高さ $(\mathrm{P} 2,3)$ 、親柱・ 冠木の幅 $(\mathrm{P} 4,5)$ 、小屋根の高さ $(\mathrm{P} 6)$ 、左右の蜻羽の出 $(\mathrm{P} 7,8))$ に従っ て生成するオブジェクトとして記述した。また扉については、とり あえず7つの補助パラメー夕(P9〜15)を用いて、奈良町において観 察された意匠についてのみ、その生成手続きを記述した（図9)。

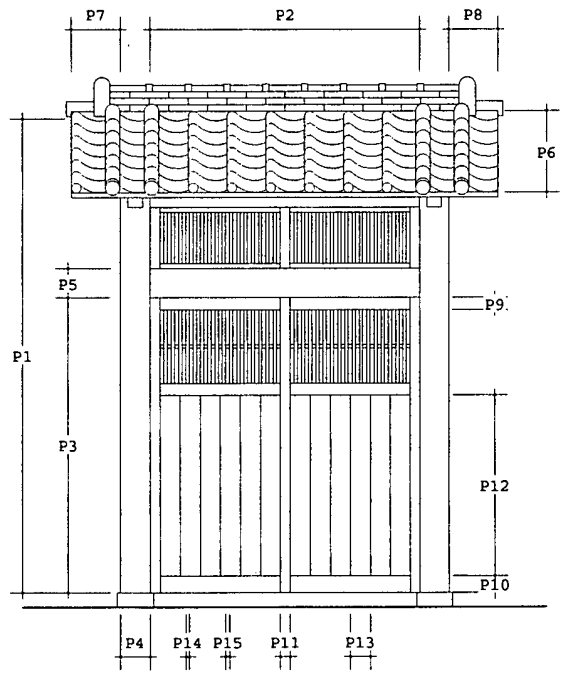

図9 門のパラメータ

5-12. 板塀オブジェクト $\left(\mathrm{H}_{22}\right)$

門オブジェクトに平行して、設置する位置のGL上両端二点を指示 することで入力することとし、定量的パラメータに従って上側の意 匠を生成するオブジェクトとして記述した。

なお、それぞれのオブジェクトにて指定される個々のパラメータ は、意匠のバリエーションごとに文献資料による図面および奈良町 における実測値から導き出された上限値・下限值をできる限り設定 し、その範囲内の值しか受け付けないような手続きを付加し、景観 シミュレーションに際して標識を変更してもより現実的な町屋ファ サードが生成されるようにした。以上の機能を全て含めても、ライ ブラリーは総計でも約 $300 \mathrm{~KB} と 大$ 変コンパクトなものとなった。 


\section{6. 町屋ファサードの再現}

図10〜11は、先にダイアグラムで示した町屋について、本研究で 作成した造形ライブラリーのみを用いて再現したファサードである。 ライブラリーを利用するためには数多くのパラメータ操作が必要に 見えるが、オブジェクトは実測に基づくデフォルトの值で生成され るため、オペレーションは微細な修正のみで対応できる。厳密に見 ると、全ての意匠構成要素が方形の領域を基本とするために、微妙 な傾斜が表現されていなかったり、全ての納まりがパラメータによ る手続きのみで決められるため、部分的に実測値との間で若干のズ レが生じているが、例えば図10は12個のオブジェクトで、図11は15 個のオブジェクトでと、いずれも少数のプラグインオブジェクトの みでほほ再現できることが確認された。

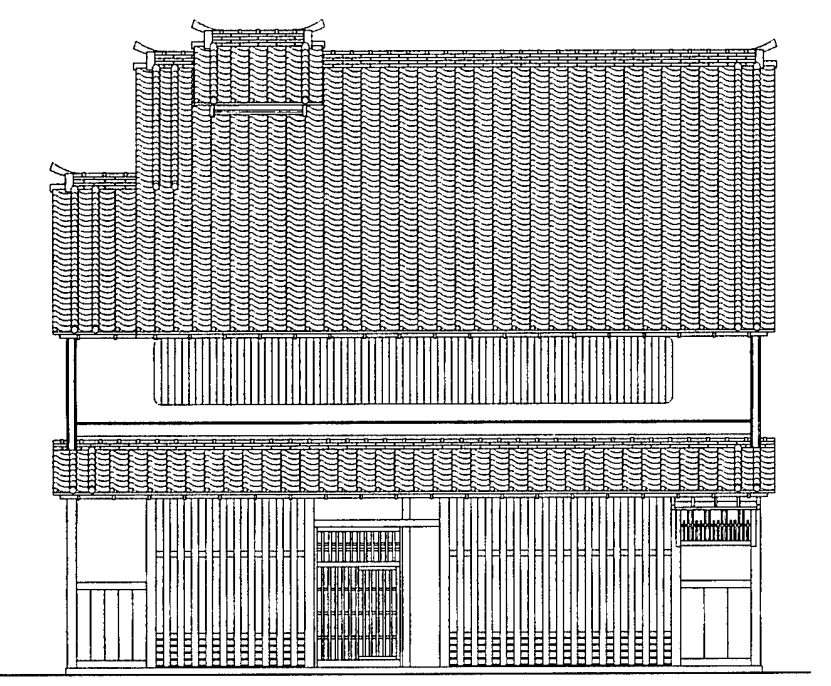

図10 町屋1（東城戸町）

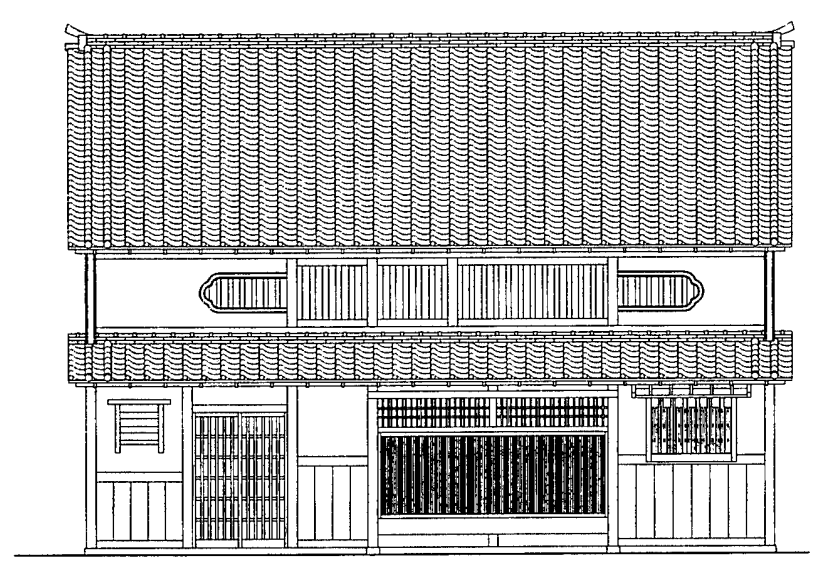

図11 町屋2（芝新屋町）

本ライブラリーを用いてコンピュータ上で概ね再現可能な町屋フ アサードは奈良町全体で現存する町屋の7〜8割程度である。これは、 現状では造形ライブラリーが基本的に切妻平入の町屋を対象として
いること、特殊な意匠の虫籠悹や出格子空には対応できないことが 主な理由である。また、構造体はそのままでもファサードの構成要 素が近代的建具等に変亘されてしまっている町屋については、完全 な再現の対象外とせざるを得ない。

\section{7.おわりに}

本研究で作成された站形ライブラリーにより、伝統的街並み調査 等で実測される現存の町屋のファサードを簡便にコンピュータ上で 再現できるだけでなく、パラメータの変更による町屋のファサード 変化をシミュレーションすることで、既存施設の増改築や歯抜けに なった敷地への新規建設等に際した修景案の検討等の際にも利用す ることが可能であると考えられる。

町屋の意匠は地域により様々であり、今回は奈良町を対象に、調 査・実測値に基づいて、その構成要素の意匠ルールの記述やパラメ 一夕の闘値を設定したが、より多くの街並み調查を参考に生成手続 きやパラメータを精緻化することで、他の地域へ適応範因が広がる ことも期待できる。また、ダイアグラムの構造からパターンを抽出 し、その町屋の機能との関係を分析することで、意匠ルールに反映 させることも可能であうう。

一方、造形ライブラリーが簡便に利用できるように、開発環境と してVectorScriptを使用したが、言語仕様の制限から、一つのオブ ジェクト内での意匠ルールを記述できるが、オブジェクト間の制約 についての記述は不完全であり、広い意味での形態文法の実現には 至っていない。例えば、袖壁が延びて卯建つが上がる場合の、軸組 オブジェクトや瓦屋根オブジェクトの螻羽との取り合いの相補的な 処理を記述できていない。また、現状では 2 次元のファサード生成 までであり、例えば街立の連続立面の作成・検討には有用であるが、 より一般に分かりやすい景観シミュレーションを考えた場合、やは り 3 次元化が望ましく、これらが今後の課題である。

謝辞

本研究は、ユニオン造形文化財団より平成 13 年度の研究助成を得 て行われた。奈良国立文化財研究所からは、伝統的建造物保存対策 調査時に町屋の実測図が描かれた野帳の写しを提供いただいた。ま た、筑波大学の藤川昌樹氏からは、建築史・都市史の立場から様々 なアドバイスを受けた。記して謝意を表す。

\section{参考文献}

1) 上田篤、土屋敦夫编：町屋共同研究、鹿島出版、1975

2)上田篤偏：京町经コミュニティ研究、麇島出版、1981

3）川崎清・小林正美・大森正夫 : 仕組まれた意匠、鹿島出版、1991

4) 門内輝行; 街並改の景観に関する記号学的研究、東京大学学位論文、 1996

5) W.Mitchell:Logic of Architecture, MIT Press, 1990 (長倉威彦訳 : 建築の形態言語、鹿島出版、1991)

6) 渡辺俊、渡辺仁史：建築設計のための知識表現モデルに関する研究、 日本建築学会計画系論文集第443号、pp.71 78,1993.5

7) S.Watanabe : Knowledge Integration for Architectural Design, Knowledge-Based Computer-Aided Architectural Design, ( editors G.Carrara and Y.Kalay ), Elsever, pp.123 146, 1994 


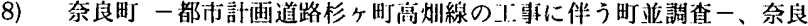

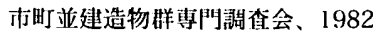

9) 奈良町（I）(元興寺周辺地区）－一沿和57年度伝統的建造物样保存対 策陚查冁告書一、奈良国立文化財研究所、1983

10）奈良町（II）（奈良町東地区）一昭利158年:度伝統的建造物群保存対策

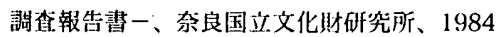

II）奈良町（III）（奈良町西地区）一昭和59年度伝統的建造物群調査報告 書一、奈良市教育委員会、1985

12）奈良町（IV）（奈良町北地区）一昭和60年度伝統的建造物群調査報告 書一、奈良市教育委員会、1986

13）奈良町 (V) 一昭和61年度伝統的建造物群保全構想報告毒一、奈良 市教育委員会、1987

14）川寄源太郎：大和名勝家商案内記 奈良之部、1884

15）和風建築社企画・編集：格子の表構えー和をきわだたせる意匠一、 学芸出版、1996

16) 木造建築研究フォーラム偏：図説 木造建築事典、学芸出版社、1995

17) R.Coyne, M.Rossenman, A.Radford, M.Barachndran and J.Gero : Knowledge-Based Design System, Addison Wesley, 1990 (渡边俊、 横沢正人共訳 : デザインの知識工学、オーム社、1994)

注

注1）文献4によれば、記号のレパートリーは階層的に整理され、その内の 建築(A)は付属物 $(\mathrm{H})$ と主屋(B)というサブカテゴリーに、また主屋(B)

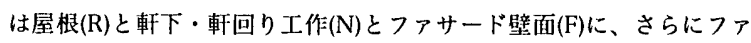
サード壁面 $(\mathrm{F})$ は点的要素 $(\mathrm{D})$ と柱・梁等 $(\mathrm{C})$ と開口部 $(\mathrm{O})$ と壁面(W)に分 類できるとしている。また、それぞれを紐分化したカテゴリーは、

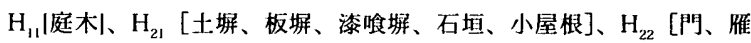
木・こみせ]、B [平屋建て、剭子二階建て、二階建て] [平入り、妻

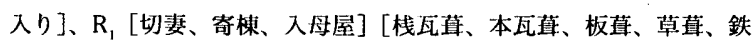

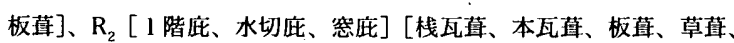
鉄板苜]、 $R_{3}$ [㶹出し $] 、 R_{4}$ [軒隅飾り、妻飾り]、 $N_{1}$ [卯建、袖壁]、 $\mathrm{N}_{2}$ [鼻隠し板、幕板]、 $\mathrm{N}_{3}$ [軒裹装飾]、 $\mathrm{N}_{4}$ [駒寄世 (犬矢来)、つま ぞめ]、 $N_{5}$ [床几 (揚見世) $、 D_{1}$ [看板、箭]、 $D_{2}$ [持送り、腕木]、

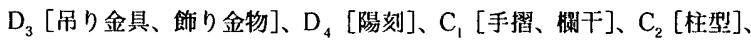
$\mathrm{C}_{3}$ [出桁 $] 、 \mathrm{C}_{4}$ [梁、胴差、貫、框 $] 、 \mathrm{O}_{1}[$ [細格子、荒格子 $[$ [平格子、 付格子、出格子] [親子格子、菱格子、捻り格子]、 $\mathrm{O}_{2}$ [障子戸、板

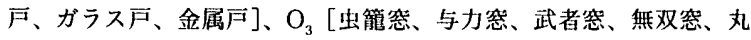

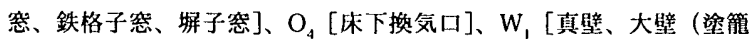
壁)］[漛喰壁、板壁、なまこ壁、土壁]、 $\mathrm{W}_{2}$ [F袋］といった [] 内 に示される標識をとりうるとしている。

注2) 柱・梁等(C)のサブカテゴリー $\left(\mathrm{C}_{1} 、 \mathrm{C}_{2} 、 \mathrm{C}_{3} 、 \mathrm{C}_{4}\right)$ については、ダイ アグラムが煩雑になるために、ここでは記述を省いた。

注3） 2000 年〜01年調査時の写真では入り口脇の与力慧がなくなっている か、1982年の奈良国立文化財研究所の調査時点ではその存在が確認 されている。

注4) VectorScriptは、汎用CADシステムであるVectorWorksの機能挀㖘 言語であり、基本的にPASCALの言語仕様にグラフィックスの関数群 が付加された体系となっている。プラグインオブジェクトの機能は、 VectorWorks8.5から利用可能であり、本研究で開発した造形ライブ ラリーは、Vectorworks9.0上で動作する。
注5) 本研究で作成した12種類のプラグインオブジェクトは、文献4の分類 にあてはめると、 $\mathrm{H}_{21}, \mathrm{H}_{22}, \mathrm{R}, \mathrm{C}, \mathrm{N}_{1}, \mathrm{~N}_{4}, \mathrm{~N}_{5}, \mathrm{O}_{1}, \mathrm{O}_{2}, \mathrm{O}_{31}, \mathrm{O}_{32}$, Wに相 当する。Rに統合された理由は指針の(2)に、Cに統合された理由は指 針の(3)に、 $\mathrm{O}_{3}$ が $\mathrm{O}_{31}, \mathrm{O}_{32}$ の二つに細分化された理由は指針の(4)に、 Wに統合された理由は指針の(5)による。

注6）法連格子は駒寄せが進化したものであるとの説もあるが、本研究で は、その設えから通常通り格子㝕のバリエーションとして报った。

注7）図5は格子空の全てのパラメー夕を説明するために都合の良い意匠と して採用したもので、系屋格子では格子台と台輪の間に中敨居を入れ ないのが一般とされているが、奈良町では図6に示すような設えの格 子恝が確譛されている。

注8）奈良町では観察されていないか、例えば複数の出格子案が配置され た壁/土塀の意匠などに対応するために、出格子䓗／与力空等は独立 したオブジェクトとして入力することも可能とした。

注9) 本文中のパラメータの総数と図8で示される数が異なるのは、出格子 㲅の意匠を用いてパラメー夕の位置を図示しているために、主に与力 悹の意匠を生成する際に用いられるパラメータである上框・方立の角 柄が示されていないことによる。

（2002年 5 月 16 日原稿受理，2002年10月 2 日採用決定） 